\section{Bioethics panels may be threat to public debate on research}

Paris. The proliferation of bioethics committees risks allowing small groups of individuals to hijack the debate over ethical issues raised by progress in research in biology and medicine, according to Philippe Lazar, the director general of the French biomedical agency, INSERM.

In a book just published in Paris, L'Éthique biomédicale en question ", Lazar complains that the French national consultative committee on bioethics has changed from a forum for informed public debate to a source of "ready-to-use" solutions to a wide range of ethical problems, often strongly influencing the regulation of new techniques.

Such committees, he says, are inclined to seek consensus on ethical issues, but a lack of consensus is the "essence" of genuine ethical debate in society; a desire for consensus can allow a few individuals to "confiscate" a debate before it has been fully explored. Lazar goes on to question whether France's comprehensive bioethics legislation, finally passed last year, sufficiently respects the diversity of opinions on bioethical issues. Under the heading "A forced consensus?", he warns that Parliament's approval of such legislation may have led the public to mistakenly believe that the problems of bioethics have been solved.

"Nothing could be less certain," says Lazar, arguing that legislation cannot, for example, reconcile the views of a religious individual convinced that human life begins at fertilization, and a hardened atheist who believes in the progressive 'humanization' of the fetus during gestation. A secular democracy needs to accept such differing beliefs, so should refrain from legislating on bioethics, concludes Lazar.

Indeed, Lazar questions whether biomedical ethics in France would be very different if the new legislation had never been introduced. He expresses confidence that society's collective "ideological apparatus" effectively prevents major abuses of new medical technologies. The demand for bioethics legislation, he argues, is symptomatic of society's fear of change.

Mankind's confidence, says Lazar, is now so low that we cannot accept that society is able to make the best use of new research results. This is reflected by an overemphasis in bioethical debates on the potential abuses of scientific progress, rather than on the new possibilities it offers. "Unconsciously or not", he argues, such emphasis reinforces opposition to scientific progress.

Declan Butler

*Philippe Lazar, L'Éthique biomédicale en question, eds Liana Levi, Paris, 1996.

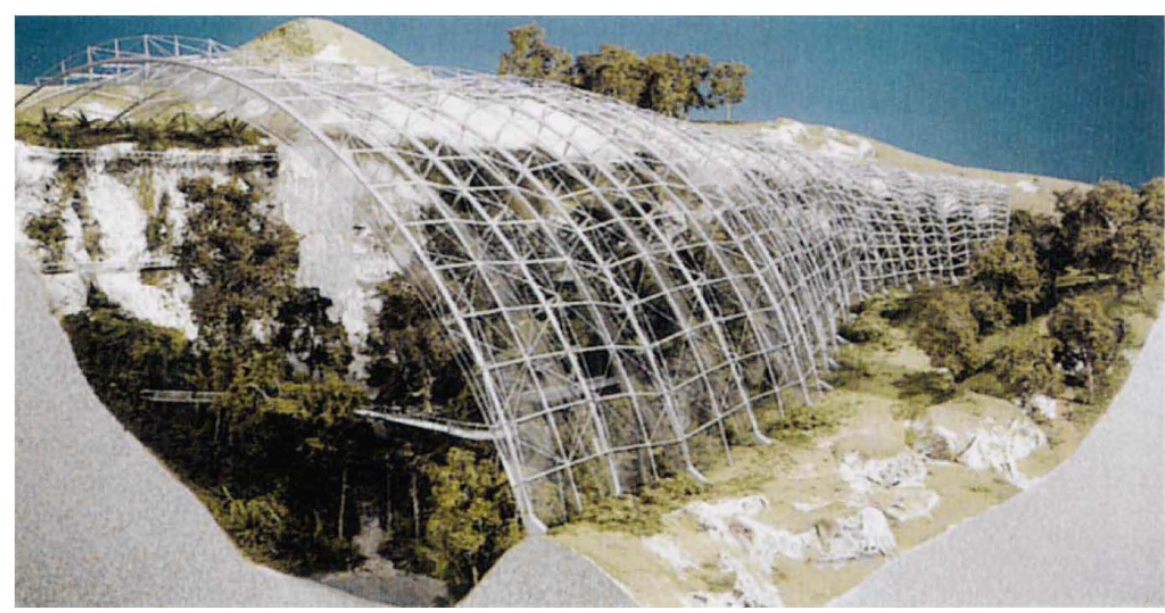

Under wraps: Eden Project hopes to raise funding from Britain's Millennium Commission.

\title{
'Clay-pit to paradise' scheme
}

London. A £106-million (\$160-million) project planned to create a series of massive covered eco-systems within a disused china clay pit in Cornwall is due to be unveiled in London this week, in preparation for a bid for funding from the national Millennium Commission.

The scheme is the brain-child of Tim Smit, and is based on his recent experience in turning a rediscovered Victorian garden, previously used to grow a wide variety of fruits and other plants obtained from all over the world and now known as the "Lost Gardens of Heligan", into one of Cornwall's leading tourist attractions, drawing over 200,000 visitors last year.

But as well as providing a broad educational experience, the scheme - known as the Eden Project - also aims to provide a research environment for scientists keen to study a range of phenomena, from the behaviour of large groups of plants, to the possibility of making commercially valuable products out of Third World crops.

"Initially we will have our own research facilities, but we are also want to become an international institution that outside researchers can use to develop their own research projects," says Smit, pointing out that the size of the scheme alone - the total covered area will be 8 hectares - and its resultant ability to carry out studies of large plant populations, make it significantly different from Biosphere 2 in the United States, whose total covered area is only 66,000 square metres.

Initially four key climatological regions will each be encapsulated in separate but connected 'biomes', namely rain forest, semi-desert, sub-tropics and Mediterranean, on the basis that these produce "not only greater biodiversity, but also the widest range of plants used by man". Visitors will pass through the biomes along a series of walkways, at one point descending from the canopy of a rainforest (see above), at another, crossing a wide stretch of desert.
Smit hopes to obtain funds for each of the biomes from foreign countries - a condition of obtaining money from the Millennium Commission, whose own funds come from the National Lottery, is that grants are matched by outside contributions - and that the research it will be able to house "could provide solutions to many of the issues surrounding global sustainable development". Indeed, any profits from the project will be used to fund research programmes explicitly in line with Agenda 21, the action plan agreed at the Earth Summit held in Rio de Janeiro in 1992.

The Eden Project already boasts an impressive bank of supporters. One key scientific adviser is Sir Ralph Riley, a former secretary of the Agricultural and Food Research Council who remains active in agricultural development projects across the world; Ghillean Prance, the director of the Royal Botanic Gardens at Kew, and another potential scientific adviser, describes it as "a very exciting project".

The architecture of the scheme has also been planned on a grand scale. The chief architects are Nicholas Grimshaw and Partners, perhaps best known for their awardwinning design for the new international terminal at Waterloo Station in London which - like the planned Eden Project uses broad spans of toughened glass to provide a combination of light and space.

The imaginative scope of the project, including the fact that it will make use of land which is currently a derelict eye-sore, is expected to attract the attention of the Millennium Commissioners, who have been keen to emphasize their interest in innovative projects which can at the same time prove their social value.

But Smit also claims that the criterion of the success of the planned project "will not be the magnificence of its building or gardens", but its ability to act as a symbol of "mankind's shift from exploitation to conservation". 